\title{
Employee Relations and Retention at Indira Projects and Developments (T) Private Limited, Chennai
}

\author{
Nanda Kumar, S. Praveen Kumar
}

\begin{abstract}
Representative relations and maintenance is a basic and progressing exertion. Probably the greatest test in having administrators in the spot that comprehends it is their obligation to make and support a domain that encourages maintenance. Staff requires fortification, course and acknowledgment to develop and stay fulfilled in their positions. Administrators must perceive this and comprehend that building up such essentials shows their targets to help nature and propel etheir representatives.

The fundamental targets of this examination is to know the reasons, why whittling down happens, to distinguish the variables which cause representatives to disappoint, to know the acceptable degree of representatives towards their activity and working conditions and to discover the zones where Indira venture and improvement enterprises.

Maintenance is a deliberate move by an association to make a domain which connects with representatives as long as possible. A progressively point by point and ongoing meaning of the idea of maintenance is 'to keep the loss of skillful workers from leaving efficiency and benefit. "Representative Retention is a precise exertion by workers to make and cultivate a situation that address the issues of the present representatives and urges them to stay utilized by having approaches and practices set up that address their various needs". In this way, it is a procedure where the workers are urged to stay with the association for the greatest timeframe or until the finishing of the undertaking
\end{abstract}

Keywords: Maintenance

Representative Retention, Time frame,

\section{INTRODUCTION}

Business relations, independent of the business, time, spot, and individuals drew in, and culture, is common, corresponding, and reliant. A significant part of all work relations is coherence. In any case, neither the business nor the workers are guaranteed of that congruity in shared relations for reasons that might include both or both of them. [1],[3],[5] During a period of monetary and business steadiness the connections between the two are steady. It additionally advances a feeling of responsibility and dependability toward the association and the activity. Be that as it may, in an unpredictable domain or in an air of quick industrialization the conditions change. The development and improvement of new enterprises while giving chances to

Revised Manuscript Received on July 22, 2019.

Nanda Kumar, Department of MBA, Bharath Institute of Higher Education and Research, Chennai, India.

Email: praveenkumar.mba@bharathuniv.ac.in

Dr. S. Praveen Kumar, Department of MBA, Bharath Institute of Higher

Education and Research, Chennai, India.

Email: praveenkumar.mba@bharathuniv.ac.in the administration and the representatives present numerous issues and difficulties. Associations in the new business consistently face the shortage of right sort of labor. This circumstance frequently acquires numerous difficulties to the business while giving wide chances and advantages to the workers (work searchers).

The most basic test the businesses particularly in new ventures face is the high pace of wearing down brought about by the shortage of labor combined with constantly expanding interest for labor. The test the business appearances isn't simply restricted to high whittling down rate however the more significant issue is holding the performing workers in their employments and with the association for a generally longer timeframe. The business needs to convey every one of his aptitudes and knowledge in holding the workers and keeping the whittling down rate at a low level. [2],[4],[6]

This is the circumstance the businesses in the Construction business in India Singapore and Thailand are experiencing. In this industry new associations are normally coming into business as it is universally quickly developing industry. Be that as it may, they have the issue of getting and holding the correct sort of representatives. The business is youthful and the labor is similarly youthful while the work open doors for the youthful representatives are not restricted to the nearby work advertise but rather stretch out to the worldwide work showcase since the business is developing internationally. At the point when a worldwide open door comes, the youthful hopeful worker is quick to get the chance and move away from the commonplace condition. No business can keep him from looking for the new chance. The pro chief of individuals is consistently on his toes to comprehend the beat of the representatives. He is essentially in dim persistently with respect to what is available - regardless of whether the representatives return home after the day's worth of effort return the following day to work in the association or do they take a 12 PM trip to US or some other nation. He needs to routinely tap various wellsprings of labor supply. Enrollment of individuals in the conditions has turned into a master work inside human asset the board work in these associations. [7], [9], ,[11]

Maintenance is an intentional move by an association to make a situation which draws in representatives as long as possible. A progressively nitty gritty and ongoing meaning of the idea of maintenance is 'to keep the loss of skilled workers from leaving efficiency and benefit. "Worker relations and maintenance is a deliberate exertion by representatives to 
make and cultivate a domain that address the issues of the present workers and urges them to stay utilized by having approaches and practices set up that address their various needs". In this manner, it is a procedure wherein the representatives are urged to stay with the association for the greatest timeframe or until the finishing of the venture. As per Harvard Business Essentials, Employee

Maintenance is the opposite of turnover. Worker relations and maintenance is useful for the association just as the representative. Representative relations and maintenance demonstrates the capacity of an association to hold its workers. Representative relations and maintenance can be spoken to by a basic measurement (for instance, a standard for dependability of $60 \%$ typically shows that an association kept $60 \%$ of its workers in a given period). Be that as it may, many think about Employee relations and maintenance as identifying with the endeavors by which managers endeavor to hold representatives in their workforce. In this sense, maintenance turns into the procedures as opposed to the result. In straightforward words Retention is the level of workers staying in the associations. Utilizing this definition, a high degree of consistency isn't really something worth being thankful for consistently. It incorporates poor entertainers that a business reluctant to terminate because of a paranoid fear of claims, just as miserable representatives who don't relinquish their professions because of funds, a feeling of commitments or a few reasons. [8], [10],[12]

Representative relations and maintenance is something other than keeping workers at work. It is additionally about supporting workers, essentially by upgrading their Job fulfillment, thusly, can build profitability and keep representatives stimulated and propelled to put forth a strong effort. Occupation fulfillment can compare to representatives who stick with their present business and endeavor to perform at or above desires and models. Representative relations and maintenance is ordinarily considered to mean the capacity to keep up the steady workforce. It is regularly connected to assurance and to hierarchical efficiency. When we talk about high maintenance, we are really looking at amplifying the quantity of good workers who are increasingly effective and gainful. Some of the time individuals will leave for reasons outside our ability to control yet there is a great deal to do to urge representatives to remain in the association cheerfully and beneficially. Along these lines Retention likewise includes substituting the underperformers for the high achievers. In basic words, a genuine maintenance strategy should concentrate on loosing the failures and keeping the guardians. The center ought to be to advance the conservation of a workforce that is capable address the organization's issues. Also, worker turnover is vital so as to evacuate representatives who can't meet the targets of the association. Holding the representatives, particularly the performing workers, isn't basic just to the new enterprises like the Construction business. Holding great or performing representatives has been a test up and down the course of industrialization. Bosses have given part of noteworthiness to this issue in business relations. New and more current methodologies have been planned and created by them. They have additionally connected with the specialists to contemplate the issue of worker weakening in their associations and suggest viable maintenance systems. Thusly, "Representative relations and maintenance" has turned into a pro capacity in individuals the board and the "maintenance strategist" a master. Particularly in the US ventures, which are constantly worried about contracting the correct individuals and holding them for longer time to lessen the expense of substitutions have regularly invested parcel of energy in considering the test drawing in the pros. An audit of writing on Employee relations and maintenance draws out that two noteworthy examinations on Employee relations and maintenance Strategies are accessible to the benefit of the US ventures and managers. The main examination was led and around two decades back by Roger E. Herman - who is viewed as the Father of Employee relations and maintenance. This examination distributed in 1991 is titled as "Keeping Good People: Strategies for Solving the Dilemma of the Decade". The subsequent one was by Gregory P Smith, who based on his broad work has distributed in 2007 a book under the title "401 Proven Ways to Retain Your Best Employees".

Both these cooperates give a comprehensive rundown of techniques to hold workers in their occupations which could be received by any business with or without alteration. However this investigation on Employee relations and maintenance Strategies was embraced to indentify the maintenance procedures by and by in Indian and worldwide IT associations. Simultaneously it was felt fundamental to look at whether the procedures that have demonstrated viable in holding workers in US businesses have any similitudes to the Indian bosses' practices. Another goal of this investigation was to discover the impression of the administrators and non-troughs in the Indian associations about the Employee relations and maintenance procedures that are supported by the two American experts.

In spite of the fact that this investigation essentially intended to cover the Construction business in India Singapore and Thailand on an example premise, it was at long last chosen to have the contextual investigation approach. As needs be nine IT associations were chosen considering the requirements of time and distraction of the administration individuals with their official obligations. These nine Cases, to a huge degree, do speak to the Construction business in India Singapore and Thailand. They incorporate associations of various size (running from 200 to 120,000 representatives), the associations in various spaces of associations having a place with Indian business people and global organizations, and, all the more significantly, the associations that have been in presence since the start of the business in India Singapore and Thailand itself too the ones that have appeared during the most recent five years. These nine cases were considered additionally utilizing the investigative elucidating study technique and gathering information through surveys and meetings, sites and associations' very own writing. [13], [15],[17]

\section{STATISTICAL TOOLS USED FOR ANALYSIS}

The primary data have been collected from the potential respondents from different 
areas and has been properly sorted, classified, edited, tabulated in a proper format and analyzed by deploying appropriate statistical tools. The statistical tests are conducted at 5 per cent level of significance. The following statistical tools are used.

- Descriptive Analysis.

Table 1- Promotion Opportunities

\begin{tabular}{|l|l|l|}
\hline PARTICULAR & FREQUENCY & PERCENTAGE \\
\hline Strongly Disagree & 9 & 9 \\
\hline Disagree & 28 & 28 \\
\hline Neutral & 32 & 32 \\
\hline Agree & 23 & 23 \\
\hline Strongly Agree & 8 & 8 \\
\hline Total & $\mathbf{1 0 0}$ & $\mathbf{1 0 0}$ \\
\hline Source: Primary data &
\end{tabular}

Figurer 1- Promotion Opportunities

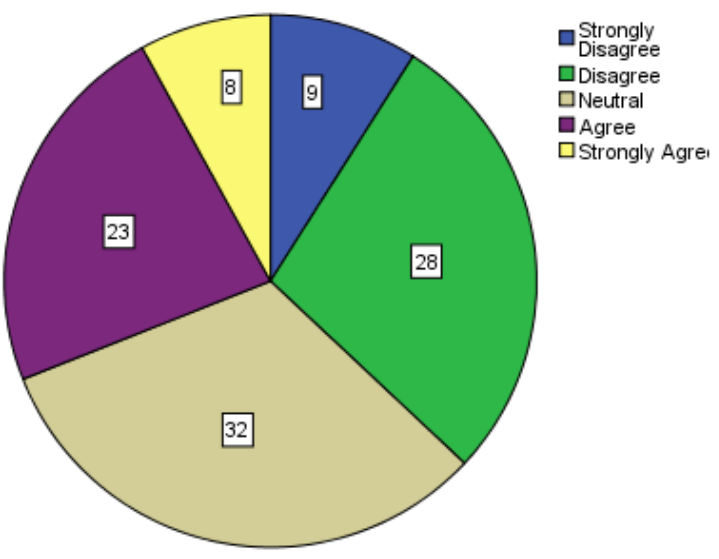

\section{Inference:}

It can be seen from Table 4.6 that $9 \%$ of the respondents rated Strongly Disagree $28 \%$ of the respondents are Disagree, $32 \%$ of the respondent are rated Neutral, and $23 \%$ of the respondents are rated as Agree, remaining $8 \%$ of the respondents are Strongly disagree.

Table 2 - Welfare Measures

\begin{tabular}{|l|l|l|}
\hline PARTICULAR & FREQUENCY & PERCENTAGE \\
\hline Strongly Disagree & 10 & 10 \\
\hline Disagree & 24 & 24 \\
\hline Neutral & 33 & 33 \\
\hline Agree & 26 & 26 \\
\hline Strongly Agree & 7 & 7 \\
\hline Total & $\mathbf{1 0 0}$ & $\mathbf{1 0 0}$ \\
\hline
\end{tabular}

Figure 2 - Welfare Measures

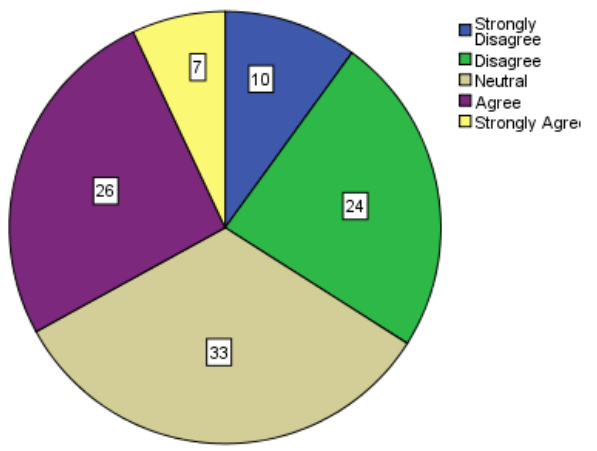

\section{Inference:}

It can be seen from Table 4.7 that $10 \%$ of the respondents rated Strongly Disagree $24 \%$ of the respondents are Disagree, $33 \%$ of the respondent are rated Neutral, $26 \%$ of the respondents are rated as Agree, remaining 7\% of the respondents are Strongly disagree.

Table 3 - Training and Development Programs

\begin{tabular}{|l|l|l|}
\hline PARTICULAR & FREQUENCY & PERCENTAGE \\
\hline Strongly Disagree & 5 & 5 \\
\hline Disagree & 23 & 23 \\
\hline Neutral & 31 & 31 \\
\hline Agree & 30 & 30 \\
\hline Strongly Agree & 11 & 11 \\
\hline Total & $\mathbf{1 0 0}$ & $\mathbf{1 0 0}$ \\
\hline Source: Primary data & &
\end{tabular}

Figure 3 - Training and Development Programs

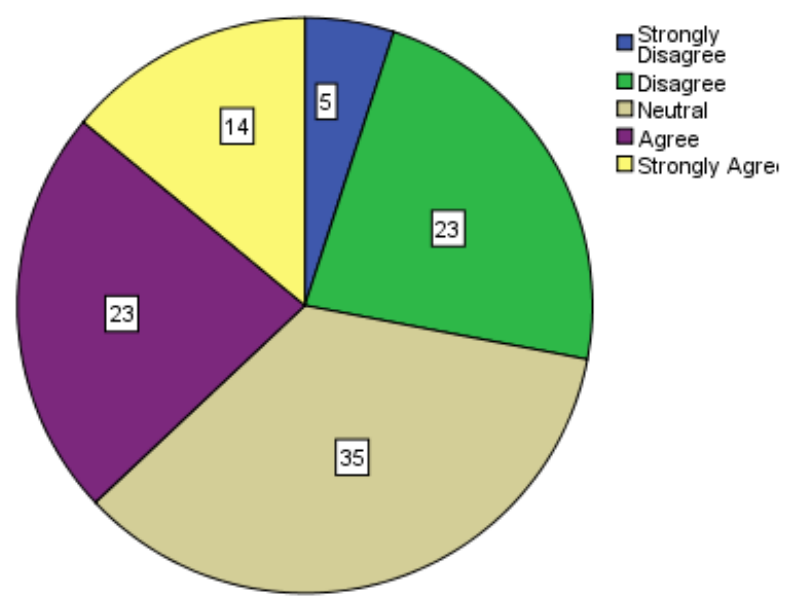

\section{Inference:}

It can be seen from Table 4.8 that $5 \%$ of the respondents rated Strongly Disagree $23 \%$ of the respondents are Disagree; $35 \%$ of the respondent are rated Neutral, $23 \%$ of the respondents are rated as Agree, remaining $14 \%$ of the respondents are Strongly disagree.

Table - 4 Provision To Avoid Sound In Plant Is Good 


\begin{tabular}{|l|l|l|}
\hline PARTICULAR & FREQUENCY & PERCENTAGE \\
\hline Strongly Disagree & 6 & 6 \\
\hline Disagree & 16 & 16 \\
\hline Neutral & 39 & 39 \\
\hline Agree & 29 & 29 \\
\hline Strongly Agree & 10 & 10 \\
\hline Total & $\mathbf{1 0 0}$ & $\mathbf{1 0 0}$ \\
\hline Source: Primary data &
\end{tabular}

Figure - 4 Provision To Avoid Sound In Plant Is Good

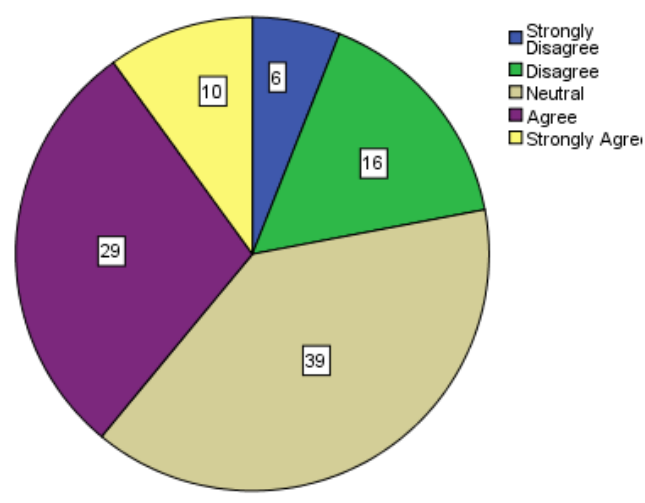

\section{Inference:}

It Can Be Seen From Table 4.9 That $6 \%$ Of The Respondents Rated Strongly Disagree $16 \%$ Of The Respondents Are Disagree, 39\% Of The Respondent Are Rated Neutral, 29\% Of The Respondents Are Rated As Agree, And Remaining 10\% Of The Respondents Strongly Disagree.

Table - 5 Cleanliness maintained in the organization is good

\begin{tabular}{|l|l|l|}
\hline PARTICULAR & FREQUENCY & PERCENTAGE \\
\hline Strongly Disagree & 3 & 3 \\
\hline Disagree & 14 & 14 \\
\hline Neutral & 30 & 30 \\
\hline Agree & 45 & 45 \\
\hline Strongly Agree & 8 & 8 \\
\hline Total & $\mathbf{1 0 0}$ & $\mathbf{1 0 0}$ \\
\hline
\end{tabular}

Figure - 5 Cleanliness maintained in the organization is good

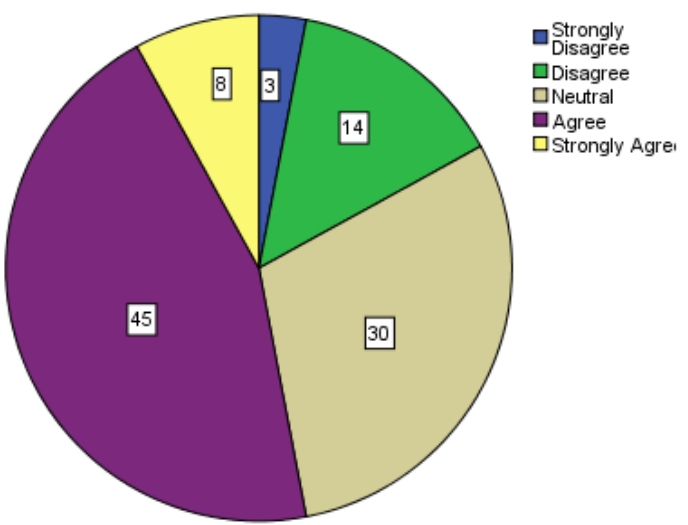

\section{Inference:}

It can be seen from Table 4.10 that $3 \%$ of the respondents rated Strongly Disagree $14 \%$ of the respondents are Disagree, $30 \%$ of the respondent are rated Neutral, $45 \%$ of the respondents are rated as Agree, and remaining $8 \%$ of the respondents strongly disagree.

\section{RESULTS}

It can be seen from Table 4.1 that $61 \%$ of the respondents appraised Female; $39 \%$ of the respondents evaluated Female.

- It can be seen from Table 4.2 that $22 \%$ of the respondents appraised Below 20 years; $33 \%$ of the respondents evaluated 21-30 years; $24 \%$ of the respondent evaluated $31-40$ years; $21 \%$ of the respondent evaluated above 41years. [14], [16],[18]

- It can be seen from Table 4.3 that $54 \%$ of the respondents appraised Married; $46 \%$ of the respondents evaluated Unmarried.

- It can be seen from Table 4.4 demonstrates that $26 \%$ of the respondents appraised Below 15000; $28 \%$ of the respondents $15001-20000.30 \%$ of the respondent appraised $20001-30000 ; 16 \%$ of the respondent evaluated Above 30,000 .

- It can be seen from Table 4.5 that $8 \%$ of the respondents appraised Strongly Disagree $20 \%$ of the respondents are Disagree, 32\% of the respondent are evaluated Neutral, and $31 \%$ of the respondents are evaluated as Agree, remaining 12\% of the respondents are Strongly oppose this idea.

- It can be seen from Table 4.6 that $9 \%$ of the respondents appraised Strongly Disagree $28 \%$ of the respondents are Disagree, $32 \%$ of the respondent are evaluated Neutral, and $23 \%$ of the respondents are evaluated as Agree, remaining $8 \%$ of the respondents are Strongly 
oppose this idea.

- It can be seen from Table 4.7 that $10 \%$ of the respondents appraised Strongly Disagree $24 \%$ of the respondents are Disagree, 33\% of the respondent are evaluated Neutral, $26 \%$ of the respondents are appraised as Agree, remaining $7 \%$ of the respondents are Strongly oppose this idea.

- It can be seen from Table 4.8 that $5 \%$ of the respondents evaluated Strongly Disagree $23 \%$ of the respondents are Disagree; $35 \%$ of the respondent are appraised Neutral, $23 \%$ of the respondents are evaluated as Agree, staying $14 \%$ of the respondents are Strongly oppose this idea. [19], [21],[23]

- It can be seen from Table 4.9 that $6 \%$ of the respondents evaluated Strongly Disagree $16 \%$ of the respondents are Disagree, 39\% of the respondent are appraised Neutral, $29 \%$ of the respondents are evaluated as Agree, and staying $10 \%$ of the respondents firmly oppose this idea.

- It can be seen from Table 4.10 that $3 \%$ of the respondents appraised Strongly Disagree $14 \%$ of the respondents are Disagree, $30 \%$ of the respondent are evaluated Neutral, $45 \%$ of the respondents are evaluated as Agree, and remaining $8 \%$ of the respondents unequivocally oppose this idea. [20], [22], [24]

- It can be seen from Table 4.11 that $1 \%$ of the respondents appraised Strongly Disagree $14 \%$ of the respondents are Disagree, $45 \%$ of the respondent are evaluated Neutral, $30 \%$ of the respondents are evaluated as Agree, and staying $10 \%$ of the respondents unequivocally oppose this idea.

- It can be seen from Table 4.12 that $3 \%$ of the respondents evaluated Strongly Disagree $8 \%$ of the respondents are Disagree, $25 \%$ of the respondent are appraised Neutral, $38 \%$ of the respondents are appraised as Agree, and staying $22 \%$ of the respondents unequivocally oppose this idea.

- It can be seen from Table 4.13 that $3 \%$ of the respondents evaluated Strongly Disagree $16 \%$ of the respondents are Disagree, $35 \%$ of the respondent are appraised Neutral, $33 \%$ of the respondents are appraised as Agree, and staying $13 \%$ of the respondents unequivocally oppose this idea.
- It can be seen from Table 4.14 that $3 \%$ of the respondents appraised Strongly Disagree $6 \%$ of the respondents are Disagree, $29 \%$ of the respondent are evaluated Neutral, $47 \%$ of the respondents are appraised as Agree, and staying $15 \%$ of the respondents emphatically oppose this idea.

- It can be seen from Table 4.15 that $5 \%$ of the respondents appraised Strongly Disagree $23 \%$ of the respondents are Disagree, $35 \%$ of the respondent are evaluated Neutral, $23 \%$ of the respondents are appraised as Agree, and staying $14 \%$ of the respondents emphatically oppose this idea.

- It can be seen from Table 4.16 that $6 \%$ of the respondents appraised Strongly Disagree $8 \%$ of the respondents are Disagree, $27 \%$ of the respondent are evaluated Neutral, $45 \%$ of the respondents are evaluated as Agree, and staying $14 \%$ of the respondents emphatically oppose this idea.

- It can be seen from Table 4.17 that $4 \%$ of the respondents appraised Strongly Disagree $9 \%$ of the respondents are Disagree, $31 \%$ of the respondent are evaluated Neutral, $35 \%$ of the respondents are evaluated as Agree and remaining $21 \%$ of the respondents emphatically oppose this idea.

- It can be seen from Table 4.18 that $5 \%$ of the respondents appraised Strongly Disagree $22 \%$ of the respondents are Disagree, $30 \%$ of the respondent are evaluated Neutral, $29 \%$ of the respondents are appraised as Agree, and remaining $14 \%$ of the respondents unequivocally oppose this idea.

\section{DISCUSSIONS}

Arrangement essentially suggests that the administration of associations think modernly to deal with the troublesome circumstances in future. They attempt to characterize the future/expected game-plan. The issue of Employee relations and maintenance is a perpetual proble $4 \mathrm{~m}$ in the work rare industry like the indira task and improvement. Henceforth, it is basic that the administrations in this industry ought to have their arrangements characterized regarding how they ought to be manage the issue and limit the issue influencing the association. In spite of the fact that we have recorded 101 systems the IT organizations in Bangalore have received, it is recommended that they have to think and embraced their arrangements on Employee relations and maintenance offering criticalness to the accompanying vital zones of Employee relations and maintenance: [25], [27], [29]

Flexible Workplace and Work: The indira venture and advancement industry in every

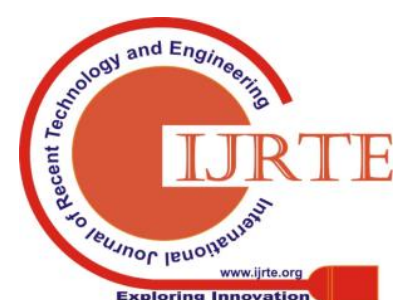


case needs to procure the information/proficient specialists. The expert laborers should be overseen by giving them adaptability of working for the association contracting them. Where the worker feels that he needs adaptable working he may not adhere on to the association. Henceforth, the organizations that don't have the arrangement of adaptability in the working frameworks need to make it an approach to accommodate adaptable work frameworks and work place plans.

Total Employee Engagement: The expert representatives likewise want to be genuinely occupied with their work and association. Such a workplace empowers to be increasingly imaginative and creative.

Both the association and the representative are profited by a workplace that accommodates absolute worker commitment. Thus, the administrations should think and always survey the representative commitment programs. It ought to be an approach of the administration to survey and reformulation. [26], [28], [30]

Employment Equity: The information laborers or the expert workers additionally like and anticipate an evenhanded business. The genuine work or assignments may differ, yet the terms and states of business can't be biased. The workers do oppose the biased business. Thus, giving work value additionally should be a normal and articulated strategy that makes the representatives to adhere on to the association.

Encourage Performance: Proficient workers do want to perform and perform to serve the association just as for their profession development and improvement. Thus, it ought to be the approach of the association to urge their workers to perform always. They have to give a favorable air to execution. Performing workers when sufficiently compensated would adhere on to the association. The administrations ought to perceive this reality through a satisfactory strategy measure.

Boost Employees' Self-Esteem: By and by it is a reality that the expert workers give very significance to confidence in their business and calling. They would not proceed in a business where their confidence is in question. Thus, the administrations all in all and the HR administrators specifically ought to make a situation that guarantees confidence of the workers all in all and of the IT experts specifically. The work and commitments made by the expert representatives should be profoundly valued and compensated. Uncommon measures ought to be arranged and created to help the representative confidence. It will likewise be a fundamental arrangement of the association.

Sense of Ownership: Another significant practice the associations ought to receive as an arrangement is to make a feeling of organization in the association with respect to its workers are worried through different estimates, for example, Employee Stock Ownership programs. At the point when the representatives feel that they are accomplices in the association - might be to a little degree - they reconsider before leaving the association. Henceforth, it ought to be an approach of the administration to make chances of representative possession in the association through worker stock proprietorship programs as well as through different methods.

\section{V.CONCLUSION}

HR the board rehearses the world over demonstrates that the job of the HR experts is evolving quickly. They are presently progressively proactive. The essential job of a HR proficient in future is empower the line administrators to play out the job of a HR chief just as choose enlistment, preparing and so on. The HR director's job will turn into the job of a preacher, where he engages, empowers the line administrators and in this manner makes the conventional HR elements of a staff chief, out of date. There may be not many HR experts in the association yet their jobs will be significant.

Representative relations and maintenance as a term did not hold a similar significance over the distinctive business fragments. For organizations working in the customary business it was understood as holding just great representatives and inspiring them to perform well. In any case, organizations working in the indira undertaking and advancement are of the assessment that maintenance means holding every one of the representatives in the organization since the organization has put a great deal in every last one of them.

The indira task and advancement industry has detailed the issue of maintenance to be the most elevated pursued by the showcasing organizations. The issue of Employee relations and maintenance is connected with the quantity of representatives - it increments with the quantity of workers. It has likewise been believed to be connected with the size of the organization. The moderate sized organizations face this issue to a huge degree. Worker relations and maintenance is a region of worry in organizations working in moderate development enterprises. Worker relations and maintenance is in this manner an element of the quantity of representatives, the size of the organization and the pace of development of the business.

The issue of Employee relations and maintenance is higher among the lesser level workers over every one of the businesses. In any case, in the dawn ventures and the indira task and advancement industry the turnover rates are high in the center just as senior levels. Over all industry fragments, the turnover among the specialized staff is higher than the non specialized staff. In any case, it is most astounding in 
the IT. The substitution just as the enlistment rate for new business is on a decrease in the conventional and administrations ventures. The enlistment rate for substitution just as new business has seen high development among promoting and IT organizations. [31], [33]

Size loans strength to the maintenance levels. Degrees of consistency have declined in the medium estimated organizations however have gone up in enormous measured associations. Conventional organizations notice that maintenance of workers isn't an issue at all since at the season of retreat in the business representatives are hesitant to leave. In showcasing organizations maintenance levels had gone up because of better development openings inside the organization yet if there should arise an occurrence of administration businesses the turnover has been fast as most open doors are detected outside. In the indira task and improvement industry, be that as it may,

the turnover rates have expanded at all levels however most organizations have turned out to be cognizant towards this and have presented better working conditions and pay bundles for all levels and specialized just as non specialized representatives.

\section{REFERENCES}

1) BharthVajan R., Ramachandran S.,Psychographic dimensions of training,2016,International Journal of Pharmacy and Technology,V-8,I-4,P-23727-23729

2) Balakrishnan P., Bharthvajan R.,A study on human resource planning in hospitals in Chennai City,2014,International Journal of Applied Engineering Research,V-9,I-22,P-7503-7507

3) Priyadarsini P., Bharthvajan R.,Role of emotional intelligence training programme in reducing the stress of the nurses,2014,International Journal of Applied Engineering Research,V-9,I-22,P-7411-7421

4) Kerinab Beenu G., Bharthvajan R.,Empirical analysis on the cosmetic buying behavior of young women in South India,2014,International Journal of Applied Engineering Research,V-9,I-22,P-7361-7366

5) Balakrishnan P., Bharthvajan R.,Whistling in the wind,2014,International Journal of Applied Engineering Research,V-9,I-22,P-7586-7593

6) Krishnan B., Peter M.,Health hazards of Indian Bpo employee-an alarming issue,2014,International Journal of Applied Engineering Research,V-9,I-22,P-7336-7341

7) Kerinab Beenu G.H., Peter M.,Role of insurance in economic development,2014,International Journal of Applied Engineering Research,V-9,I-22,P-7532-7539

8) Balakrishnan P., Peter M., Priyadarsini P.,Efficiency of safety measures for wellbeing of employees in manufacturing industry,2014,International Journal of Applied Engineering Research,V-9,I-22,P-7376-7382

9) Anbarasi M., Praveen Kumar S.,Online sales promotions of herbal products and its effectiveness towards tanisha.com,2019,Indian Journal of Public Health Research and Development,V-10,I-1,P-195-200

10) Anbarasi M., Praveen Kumar S.,Various online marketing and promotions strategies to improve the validation towards the organic products in the pharmaceutical sectors,2019,Indian Journal of Public Health Research and Development,V-10,I-1,P-263-269

11) Loganathan R., Praveen Kumar S.,Grievance handling a key factor for solving issues of employees in an organization,2014,International Journal of Applied Engineering Research,V-9,I-22,P-7483-7491

12) Loganathan R., Praveen Kumar S.,Study on preference of private label brands in super and Hypermarkets,2014,International Journal of Applied Engineering Research,V-9,I-22,P-7327-7335

13) Smitha M., Praveen Kumar S.,Understanding stress and its managementamong the nurses in Chennai city,2014,International Journal of Applied Engineering Research,V-9,I-22,P-7560-7565

14) Kerinab Beenu G.H., Praveen Kumar S.,A study on the investment behavior of Chennai investors in mutual fund schemes,2014,International Journal of Applied Engineering Research,V-9,I-22,P-7520-7525

15) Loganathan R., Praveen Kumar S.,Retention strategies key for organizational productivity,2014,International Journal of Applied Engineering Research,V-9,I-22,P-7443-7447
16) Pavithra J., Ganesan M., Brindha G.,State wise analysis of microfinance sector in India,2016,International Journal of Pharmacy and Technology,V-8,I-4,P-23417-23432

17) Pavithra J., Ganesan M.,A comparative study on microfinance in India and abroad,2016,International Journal of Applied Business and Economic Research,V-14,I-8,P-5471-5476

18) Pavithra J., Ganesan M.,A study on awareness and impact of micro-financial schemes,2016,International Journal of Applied Business and Economic Research,V-14,I-8,P-5449-5460

19) Senthilmurugan P., Pavithra J.,Consumer preference towards organised retailing with reference to Big Bazaar,2014,International Journal of Applied Engineering Research,V-9,I-22,P-7469-7475

20) Senthilmurugan P., Pavithra J.,Implication of social media marketing in growing healthcare industry,2014,International Journal of Applied Engineering Research,V-9,I-22,P-7448-7456

21) Loganathan R., Pavithra J.,Consumer perception towards private label brand over other brands in super markets and hypermarkets,2014,International Journal of Applied Engineering Research,V-9,I-22,P-7355-7360

22) Kerinab Beenu G., Pavithra J.,Tradeâ€"off between liquidity and profitability in logistics industry,2014,International Journal of Applied Engineering Research,V-9,I-22,P-7398-7401

23) Kerinab Beenu G., Pavithra J.,A study on the prospective consumerâ€(M perception towards utility cars in Chennai city,2014,International Journal of Applied Engineering Research,V-9,I-22,P-7526-7531

24) Pavithra J., Dilli Babu P., Ambuli T.V.,A study on budgetary control at Maruti Service Masters, Chennai,2014,International Journal of Applied Business and Economic Research,V-12,I-2,P-151-161

25) Pavithra J., Dilli Babu P., Ambuli T.V.,A study on customer satisfaction of retro Garments Pvt Ltd, Chennai,2014,International Journal of Applied Business and Economic Research,V-12,I-2,P-381-391

26) Kerinab Beenu G.H., Pavithra J., Senthilmurugan P.,A study on the influence of promotional activities for TATA ARIA among consumers in Chennai,2014,International Journal of Applied Engineering Research,V-9,I-22,P-7572-7578

27) Vijayaragavan S.P.,An investigative expert that's general FBG sensors,International Journal of Mechanical Engineering and Technology,V-8,I-8,PP-1500-1505,Y-2017

28) Vijayaragavan S.P.,Equalization routing protocol for Wi-Fi sensor strategy,International Journal of Mechanical Engineering and Technology,V-8,I-8,PP-1662-1666,Y-2017

29) Karthik B., Kiran Kumar T.V.U., Vijayaragavan P., Bharath Kumaran E.,Design of a digital PLL using 0.35 $\hat{\mathrm{I}}^{1 / 4 \mathrm{~m}}$ CMOS technology,Middle East Journal of Scientific Research,V-18,I-12,PP-1803-1806,Y-2013

30) Kanniga E., Selvaramarathnam K., Sundararajan M.,Kandigital bike operating system,Middle - East Journal of Scientific Research,V

31) Jasmin M., Vigneshwaran T., Beulah Hemalatha S.,Design of power aware on chip embedded memory based FSM encoding in FPGA,International Journal of Applied Engineering Research,V-10,I-2,PP-4487-4496,Y-2015

32) Jasmin M.,Optimization techniques for low power VLSI circuits,Middle East Journal of Scientific Research,V-20,I-9,PP-1082-1087,Y-2014

33) Jasmin M., Vigneswaran T.,Fuzzy controller for error control of on - Chip communication,2017 International Conference on Algorithms, Methodology, Models and Applications in Emerging Technologies, ICAMMAET 2017,V-2017-January,I-,PP-1-5,Y-2017

\section{AUTHORS PROFILE}

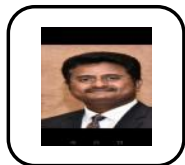

Nanda Kumar Research Scholar, Department of MBA, Bharath Institute of Higher Education and Research, Chennai, India.

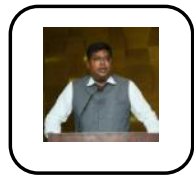

Dr. S. Praveen Kumar Professor, Department of MBA, Bharath Institute of Higher Education and Research, Chennai, India. 